\section{Journal of Technology Law \& Policy}

Volume XVI - Fall 2015

ISSN 2164-800X (online)

DOI $10.5195 /$ tlp.2015.178

http://tlp.law.pitt.edu

\title{
Microbiomes Germ Clouds and the Future of DNA \\ Jurisprudence
}

Jade Salyards

\section{$(\mathrm{Cc}) \mathrm{Br}-\mathrm{NC}-\mathrm{ND}$}

This work is licensed under a Creative Commons Attribution-Noncommercial-No Derivative Works 3.0 United States License.

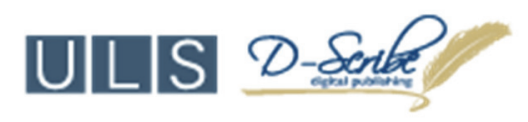

This site is published by the University Library System of the University of Pittsburgh as part of its DScribe Digital Publishing Program and is cosponsored by the University of Pittsburgh Press. 


\title{
Microbiomes Germ Clouds and the Future of DNA Jurisprudence
}

\author{
Jade Salyards ${ }^{*}$
}

A scientific study published in Science in August 2014 revealed that every human lives inside their own microbial germ cloud, which is both mobile and traceable. ${ }^{1}$ While microbiomes can potentially revolutionize the field of medicine, they may also transform the field of law by its use in tracking and identifying criminals. Part I of this paper will explain what a microbiome is and the role it plays in human health, discuss the Home Microbial Project study, and briefly discuss some precautions against the media hype surrounding microbiome studies due to the fact that the research concerning microbiomes is still in its infancy. Part II will compare the jurisprudence surrounding DNA to the possible implications that jurisprudence could have on studying the microbiome. This section will provide a brief history of DNA analysis decisions by courts leading up to the monumental decision in Maryland v. King, discuss some disadvantages of DNA analysis, and compare it to the study of microbiomes, which may be better suited for identifying criminals. Part III will discuss ethical concerns surrounding governmental collection and storage of DNA and microbiomes. Finally, Part IV posits that because microbiomes can reveal much more private information about an individual than DNA, microbiomes should be regarded with caution, and a national database should be unconstitutional.

\section{PART I: MicRobIOMES AND ITS Role IN HUMAN HEALTH}

\section{A. Microbiomes Are Composed of Trillions of Germs that Can Have Important Implications for Human Health}

Microbiomes consist of the trillions of microscopic germs that live in or on the human body. ${ }^{2}$ Microbiomes include viruses, bacteria, and fungi. ${ }^{3}$ One reason the

\footnotetext{
* J.D. Candidate, 2016, University of Pittsburgh School of Law; Alumni Chair, University of Pittsburgh Journal of Technology Law and Policy.

${ }^{1}$ Maggie Fox, Microbiomes: You Live in Your Own Germ Cloud, Study Finds, NBC NewS (Aug. 28, 2014), http://www.nbcnews.com/health/health-news/microbiomes-you-live-your-own-germcloud-study-finds-n191366.

${ }^{2}$ Bill Sullivan, 6 Things You Need to Know about Your Microbiome, THE ScOPE (Sept. 24, 2014), $\mathrm{http} / /$ thescopepopculturescience.blogspot.com/2014/09/6-things-you-need-to-know-about-your.html.

${ }^{3} I d$.

Journal of Technology Law \& Policy

Volume XVI - Fall 2015 • ISSN 2164-800X (online)

DOI 10.5195/tlp.2015.178 • http://tlp.law.pitt.edu
} 
microbiome is especially important is that the human body has more microbiomes on it than does its own cells. ${ }^{4}$ Humans are born sterile but acquire microbiomes through the birth canal and breast milk. ${ }^{5}$ Each individual's microbiome stabilizes by the age of three, although new organisms are added to the microbiome constantly as each person moves into new environments. ${ }^{6}$ Each individual's microbiome acts as a unique germ cloud that is inadvertently left behind wherever that person visits. ${ }^{7}$ Each microbiome also has a distinctive smell that is released into the air whenever an individual moves, which may explain how dogs are able to track a person after smelling something that belonged to them. ${ }^{8}$ Studies have also found that microbiomes may help protect against certain allergies or obesity. ${ }^{9}$ Microbiomes could also play a role in treating anxiety and depression. ${ }^{10}$ Microbiomes are as unique as DNA, but since microbiomes are inadvertently left behind everywhere, they may help make tracking and catching criminals easier than DNA analysis. ${ }^{11}$

\section{B. The Home Microbial Project Is the First to Discover that Microbiomes Can Be Traced and Tracked to Particular Individuals}

In the Home Microbial Project, researchers from the U.S. Department of Energy's Argonne National Laboratory and the University of Chicago monitored the microbial germ clouds of seven ethnically diverse families and their homes over a period of six weeks. ${ }^{12}$ Participants swabbed their hands, feet, and noses daily in order to collect a sample of their microbial germ clouds. ${ }^{13}$ Participants also swabbed

${ }^{4}$ Id.
${ }^{5}$ Id.
${ }^{6}$ Id.
${ }^{7}$ Jim Algar, Your Own Personal Germ Cloud: How Your Microbes Follow You Around, TECH
(Aug. 29, 2014, 4:07 PM), http://www.techtimes.com/articles/14373/20140829/your-own-
nal-germ-cloud-how-your-microbes-follow-you-around.htm.
${ }^{8}$ Sullivan, supra note 2.
${ }_{9}^{9}$ Id.
${ }^{10}$ Brian Krans, 6 Surprising Facts about the Microbes Living in Your Gut, HeALTHLINE NEws (Sept. 7, 2013), http://www.healthline.com/health-news/strange-six-things-you-didnt-know-about-yourgut-microbes-090713.

${ }^{11}$ Emery Dennel, We All Live in Our Own "Germ Cloud,” ChINA Topix (Aug. 29, 2014, 6:05 AM), http://www.chinatopix.com/articles/8276/20140829/we-all-live-in-our-own-germ-cloud-ormicrobiome.htm.

${ }^{12}$ Simon Lax et al., Longitudinal Analysis of Microbial Interaction Between Humans and the Indoor Environment, 345 SCIENCE 1048 (2014).

${ }_{13}$ Louise Lerner, Individual's Unique Microbial "Fingerprint" Drastically Affects Home Environment, Study Finds, UCHICAGONEwS (Sept. 2, 2014), http://news.uchicago.edu/article/2014/09/ 02/individuals-microbial-fingerprint-affects-home-environment-study-finds. 
doorknobs, light switches, floors, and countertops around their homes. ${ }^{14}$ Three of the families moved during the study, so participants took samples immediately before and after the families moved into their new homes. ${ }^{15}$ Remarkably, researchers found that the new homes were microbiologically similar to the old homes within one day of the family moving in. ${ }^{16}$

Researchers also found that individuals who shared frequent physical contact were likely to have similar microbial clouds..$^{17}$ In one of the homes, two out of the three occupants were in a relationship, and researchers discovered that the couple shared many more microbiomes than the other participant. ${ }^{18}$ Married couples and their children were also found to have very similar microbial germ clouds. ${ }^{19}$ Researchers found that, between participants living in the same home, hands were most likely to contain similar microbiomes, while noses were more likely to show individual variation. ${ }^{20}$

Researchers from the Home Microbial Project have suggested that microbial analysis could be a useful forensics tool for tracking criminals. ${ }^{21}$ Researchers stated that a person's microbiome can reveal the identity of the individual, where they have been, what they have eaten, and who they may have interacted with recently. ${ }^{22}$ Scientists have already worked with police in Hawaii to solve homicides by examining microbiomes. ${ }^{23}$ Microbiomes can help to provide insight as to which individual the victim in a homicide case was around right before his death. ${ }^{24}$ Fingerprints are not always detected at crime scenes, but microbiomes will always be present and are impossible to conceal, which could have profound implications for the field of forensics. ${ }^{25}$

$$
\begin{aligned}
& { }^{14} I d \text {. } \\
& { }^{15} \text { Lax et al., supra note } 12 . \\
& { }^{16} I d \text {. } \\
& { }^{17} \text { Lerner, supra note } 13 . \\
& { }^{18} I d \text {. } \\
& { }^{19} I d \text {. } \\
& { }^{20} I d \text {. } \\
& { }^{21} I d \text {. } \\
& { }^{22} \text { Algar, supra note } 7 . \\
& { }^{23} I d \text {. } \\
& { }^{24} I d \text {. } \\
& { }^{25} I d \text {. }
\end{aligned}
$$

Journal of Technology Law \& Policy

Volume XVI - Fall 2015 • ISSN 2164-800X (online) DOI 10.5195/tlp.2015.178 • http://tlp.law.pitt.edu 
There is no blanket rule for how long a microbiome will remain on a given surface. ${ }^{26}$ The amount of time and the accuracy of matching the microbiome to its host is contingent upon the environment and the type of sample analyzed. ${ }^{27}$ For example, researchers at the Human Microbiome Project found that stool samples could identify up to $86 \%$ of participants after one year, while skin samples were much less reliable. ${ }^{28}$ The Human Microbiome Project also found that microbiomes hardly ever created a false positive, meaning that it is highly unlikely that a microbiome would incriminate the wrong person. ${ }^{29}$ Microbiomes also have incredible potential when analyzing cell phones and shoes. ${ }^{30}$ Researchers believe they could distinguish between two people with a $97 \%$ accuracy rate with cell phones and a $99 \%$ accuracy rate with shoe surfaces. ${ }^{31}$

\section{The Caution Surrounding Microbiomes and Media Hype}

Some researchers caution skepticism due to fear that the microbiomes are being embellished by the media. ${ }^{32}$ Although microbiomes can and will have a profound effect on the way researchers and doctors study health in the twenty-first century, ${ }^{33}$ microbiome research is still in its infancy and must be evaluated carefully. ${ }^{34}$ For example, a 2012 study that aimed to compare the gut microbiome between elderly people who resided in elderly homes with elderly people who resided in the community suffered due to a misunderstanding between causation and correlation. ${ }^{35}$ This study proposed that poor diet altered the gut microbiome, which caused poor

${ }^{26}$ AFP, In Forensics, Microbiome May Become Next Fingerprint, DISCOVERY News (May 12, 2015), http://news.discovery.com/tech/biotechnology/in-forensics-microbiome-may-become-fingerprint150512.htm.

${ }^{27} I d$.

${ }^{28} \mathrm{Id}$.

${ }^{29} \mathrm{Id}$.

${ }^{30}$ Josiah Zayner, The Future Microbiome Forensics, BiONONYMOUS.ME, http://biononymous .me/the-future-of-microbiome-forensics/.

${ }^{31} I d$.

${ }^{32}$ William P. Hanage, Microbiology: Microbiome Science Needs a Healthy Dose of Skepticism, NATURE (Aug. 20, 2014), http://www.nature.com/news/microbiology-microbiome-science-needs-ahealthy-dose-of-scepticism-1.15730.

${ }^{33}$ Lerner, supra note 13.

${ }^{34}$ Hanage, supra note 32.

${ }^{35} \mathrm{Id}$.

M I C R O B I O M E S G E R C L O U D S

Volume XVI - Fall 2015 • ISSN 2164-800X (online)

DOI 10.5195/tlp.2015.178 • http://tlp.law.pitt.edu 
health in the patients, but failed to question whether the poor health could have altered the gut microbiome. ${ }^{36}$

Another potential problem concerning microbiome studies is that they are primarily conducted on germ-free mice, which may not adequately represent human reality. ${ }^{37} \mathrm{Germ}$-free mice pose a problem with the experiments because they are bred in a lab and do not have a natural microbiome before acquiring one from the experiment. ${ }^{38}$ Thus, the experiments have shown that the germ free mice generally have worse health after receiving a microbiome, suggesting that the absence of a microbiome may have a shielding effect against obesity. ${ }^{39}$ In essence, the microbiome is so critical to human health that, depending on the composition of each individual's microbiome, a human may be more likely to be obese or more likely to have better health. However, the results of studies with germ-free mice must be viewed with some caution because the studies do not allow for the mice in their natural state, i.e. complete with a natural microbiome. ${ }^{40}$

Research concerning microbiomes and their important effect on human health is at an exciting point. ${ }^{41}$ It is relevant to consider that some studies' results may be exaggerated by the media ${ }^{42}$ because of the tremendous potential that microbial research can have for the health of humans. Due to that possible exaggeration, it is important to remember that there may be other contributing factors to obesity and poor health that the researchers in these microbial studies are not addressing. However, despite the general caution one must have when reading microbiome studies in the media, there can be little doubt that microbial germ clouds will have an important part to play both in the realm of human health and in the study of forensics. ${ }^{43}$

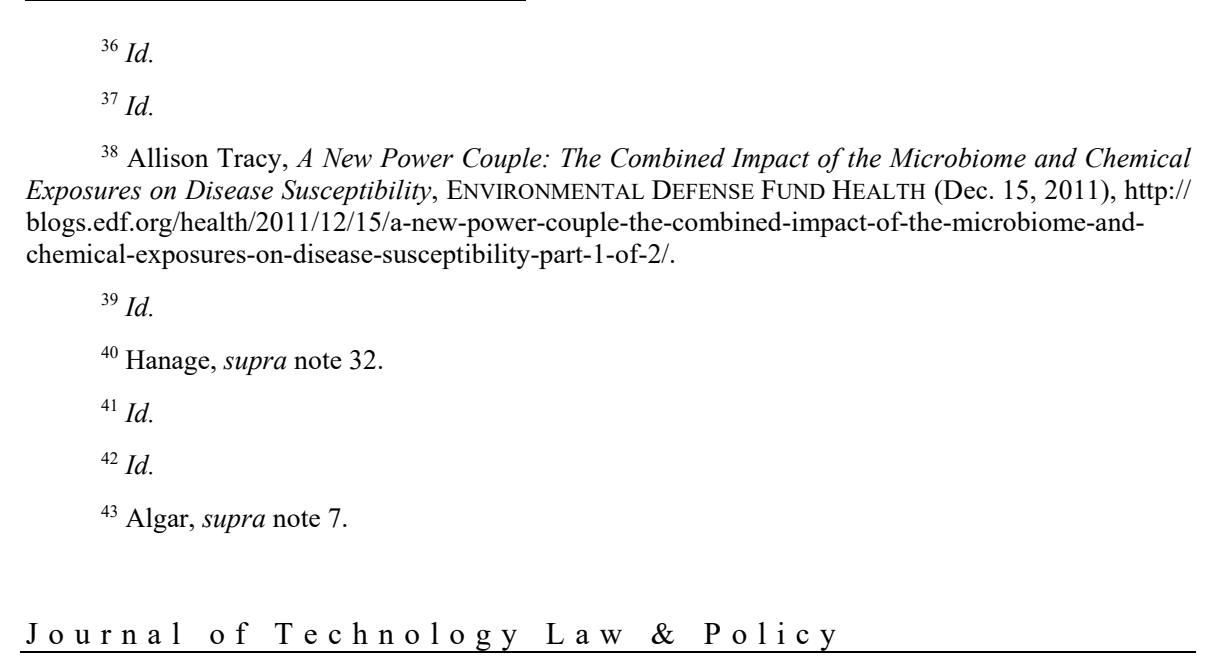

Volume XVI - Fall 2015 • ISSN 2164-800X (online) DOI 10.5195/tlp.2015.178 • http://tlp.law.pitt.edu 


\section{PART II: THE PROCESS OF DNA ANALYSIS AND ITS SIMILARITY TO MICROBIOMES}

Microbiomes are germ clouds composed of an individual's bacteria. ${ }^{44}$ They are structurally similar to deoxyribonucleic acid ("DNA") and the collection process is roughly the same. ${ }^{45}$ Therefore, a basic understanding of DNA analysis and jurisprudence is useful in determining the constitutionality concerning the collection and storage of microbiomes.

DNA is the self-replicating material present in all living organisms that carries genetic information. ${ }^{46}$ Each cell in the human body contains a complete set of DNA. ${ }^{47}$ Approximately $99.9 \%$ of DNA found in humans is exactly the same, and it is the $0.1 \%$ that makes each person distinctive. ${ }^{48}$ Scientists may test DNA either through the restriction fragment length polymorphism ("RFLP") analysis or through the short tandem repeat ("STR") analysis. ${ }^{49}$ STR analysis has grown in popularity because it requires less DNA to sample from. ${ }^{50}$ Scientists using the STR method will increase the DNA sample through a process called polymerase chain reaction ("PCR"). ${ }^{51}$ Once the DNA has been increased, scientists then study how often base pairs of nucleotides repeat in specific locations, or loci. ${ }^{52}$ The Federal Bureau of Investigation has deemed thirteen specific loci to serve as the standard for DNA analysis, since the likelihood that any two individuals (except for identical twins) would share the same thirteen loci profile is roughly one in one billion or greater. ${ }^{53}$

${ }^{44}$ Fox, supra note 1.

${ }^{45} 42$ U.S.C. $\S 14135 \mathrm{a}(2012)$.

${ }^{46}$ Deoxyribonucleic Acid (DNA), National Human Genome ReSEarch Institute (July 17, 2014), http://www.genome.gov/25520880.

${ }^{47}$ How Does DNA Testing Work?, SCIENCE (Feb. 1, 2013), http://www.bbc.co.uk/science/0/ 20205874.

${ }^{48} \mathrm{Id}$.

${ }^{49}$ William Harris, How DNA Evidence Works, HOWSTUFFWORKS, http://science.howstuffworks .com/life/genetic/dna-evidence2.htm.

$$
\begin{aligned}
& { }^{50} I d . \\
& { }^{51} I d . \\
& { }^{52} I d . \\
& { }^{53} I d .
\end{aligned}
$$

M I C R O B I O M E S G E R M C L O U D S

Volume XVI - Fall 2015 • ISSN 2164-800X (online)

DOI 10.5195/tlp.2015.178 • http://tlp.law.pitt.edu 


\section{PART III: DNA ANALYSIS JURISPRUDENCE AND THE EVOLUTION OF THE Right OF THE POLICE TO TAKE DNA SAMPLES FROM SUSPECTS}

The Fourth Amendment to the United States Constitution protects the public from any unreasonable searches or seizures by the government. ${ }^{54}$ The Constitution requires a search warrant before government officials may subject an individual to a search, whether it be on his person or through his belongings. ${ }^{55} \mathrm{~A}$ search warrant must be obtained from a neutral and detached magistrate by demonstrating probable cause. ${ }^{56}$ In Katz v. United States, ${ }^{57}$ the Supreme Court held that a "search" necessitating a warrant occurs whenever there is governmental intrusion into an area where an individual has a reasonable expectation of privacy. ${ }^{58}$ Therefore, the governmental interest must be balanced against the privacy expectation and interest of the individual. ${ }^{59}$

One of the first cases to involve taking a bodily substance without the defendant's permission involved a blood sample. In Schmerber v. California ${ }^{60}$ the petitioner was taken to a hospital in order to be treated for injuries he sustained while driving under the influence of alcohol, and was arrested at the hospital during his treatment. ${ }^{61}$ At the request of a police officer, a physician withdrew a blood sample from the petitioner and gave it to the police without petitioner's consent. ${ }^{62}$ The blood sample was then subjected to a chemical analysis, which revealed the petitioner's blood alcohol level at the time of the automobile accident..$^{63}$ That evidence was later used against him at trial. ${ }^{64}$ The Supreme Court held that the seizure of a blood sample

${ }^{54}$ U.S. CONST. amend. IV ("The right of the people to be secure in their persons, houses, papers, and effects, against unreasonable searches and seizures, shall not be violated and no Warrants shall issue, but upon probable cause, supported by Oath or affirmation, and particularly describing the place to be searched, and the persons or things to be seized.").

${ }^{55} I d$.

${ }^{56}$ Coolidge v. New Hampshire, 403 U.S. 443 (1971).

${ }^{57}$ Katz v. United States, 389 U.S. 347 (1967).

${ }^{58}$ Id. at $360-61$.

${ }^{59}$ Sheryl H. Love, Note, Allowing New Technology to Erode Constitutional Protections: A Fourth Amendment Challenge to Non-Consensual DNA Testing of Prisoners, 38 VILL. L. REV. 1617, 1618-19 (1993).

${ }^{60}$ Schmerber v. California, 384 U.S. 757 (1966).

${ }^{61} I d$. at 758 .

${ }^{62} \mathrm{Id}$.

${ }^{63} \mathrm{Id}$. at 759 .

${ }^{64} \mathrm{Id}$.

Journal of Technology Law \& Policy

Volume XVI - Fall 2015 • ISSN 2164-800X (online)

DOI 10.5195/tlp.2015.178 • http://tlp.law.pitt.edu 
from the petitioner was a search under the Fourth Amendment. ${ }^{65}$ In this case, the Supreme Court held the search was constitutional because the officer had probable cause to believe that the petitioner had been drinking at the time of the crash, that he had already been under arrest when the search had been conducted, and that it was an emergency because the alcohol was already exiting petitioner's blood. ${ }^{66}$ Although the Supreme Court held that this was a relatively minor privacy intrusion, the Court suggested that in ordinary circumstances, a warrant would be required in order to obtain a blood sample. ${ }^{67}$

The Fourth Circuit, in Jones v. Murray, was the first court to address the constitutionality of taking DNA from incarcerated felons without their consent. ${ }^{68} \mathrm{In}$ Jones, petitioners challenged a Virginia statute that required that any person convicted of a felony on or after July 1, 1990 would have to submit to DNA analysis that would then be stored and used to match with any other future crimes. ${ }^{69}$ The petitioners argued that the statute ought to require an individualized suspicion before a prisoner must submit to DNA testing. ${ }^{70}$ The petitioners also argued that the government's interest in identifying the perpetrators of future crimes was not a sufficient justification to force all prisoners to undergo DNA analysis, especially since the only evidence put forth by the government to support its interest was recidivism statistics. ${ }^{71}$ The state argued that there was no reasonable way to demonstrate individualized suspicion, since the data was intended to be used in solving future crimes. ${ }^{72}$ The state further argued that the development of its database was a special need that justified searches without individualized suspicion. ${ }^{73}$

The majority in Jones held that prisoners were a class exempt from the usual protections of the Fourth Amendment. ${ }^{74}$ The court held that although taking DNA samples from prisoners was a search under the Fourth Amendment, probable cause

\footnotetext{
${ }^{65}$ Schmerber v. California, 384 U.S. 757, 769-70 (1966).

${ }^{66} \mathrm{Id}$. at 770 .

${ }^{67} I$. at $770-71$.

${ }^{68}$ Love, supra note 59, at 1618-19.

${ }^{69}$ Jones v. Murray, 962 F.2d 302, 303 (4th Cir. 1992).

${ }^{70} I d$. at 305.

${ }^{71} \mathrm{Id}$.

${ }^{72} \mathrm{Id}$.

${ }^{73}$ Id. See also Skinner v. Ry. Labor Executives Assoc., 489 U.S. 602 (1989), holding that the special interest of having a workplace free of drugs allowed the absence of individualized suspicion in conducting mandatory drug tests for the employees.

${ }^{74}$ Id. at 307.
} 
was not a necessary perquisite to the search since the search was performed on prisoners. ${ }^{75}$ The majority engaged in a balancing test and held that the intrusion on the prisoner's privacy was slight compared to the enormous benefit the DNA database would have for society. ${ }^{76}$ The majority reasoned that DNA analysis was similar to fingerprinting, and since suspects are fingerprinted upon their arrest, there can be no expectation of privacy because the state has a legitimate interest in obtaining a person's identity at that point. ${ }^{77}$ Therefore, prisoners cannot have a reasonable expectation of privacy because they are incarcerated, and the state has a legitimate interest in law enforcement techniques that could solve future crimes. ${ }^{78}$

Similarly, in United States v. Kincade, ${ }^{79}$ the Ninth Circuit held that the DNA Analysis Backlog Elimination Act of 2000 ("DNA Act") ${ }^{80}$ was constitutional. ${ }^{81}$ The DNA Act, at issue in Kincade, required any person convicted of certain felonies and who is incarcerated or on parole, probation, or supervised release must provide officials with a bodily sample that may be used to collect and store their DNA. ${ }^{82}$ Failure to comply with the Act resulted in a misdemeanor, punishable by up to one year in prison and $\$ 100,000 .{ }^{83}$

Kincade was convicted of robbing a bank with a firearm and was sentenced to ninety-seven months in prison, followed by three years supervised release. ${ }^{84}$ After he was released from incarceration, Kincade's supervising officer asked him to submit a blood sample in accordance with the DNA Act. ${ }^{85}$ Kincade refused to submit a blood sample out of a personal preference.$^{86}$ Kincade was found to be in violation of the terms of his supervised release and was sentenced to another four months of

\footnotetext{
${ }^{75}$ Jones v. Murray, 962 F.2d 302, 306 (4th Cir. 1992).

${ }^{76} I d$. at 307.

${ }^{77} I d$. at 308.

${ }^{78} \mathrm{Id}$.

${ }^{79}$ United States v. Kincade, 379 F.3d 813 (9th Cir. 2004).

${ }^{80}$ Pub. L. No. 106-546, 114 Stat. 2726 (2000).

${ }^{81}$ Kincade, 379 F.3d at 844.

${ }^{82}$ Id. at $816-17$.

${ }^{83} \mathrm{Id}$.

${ }^{84} \mathrm{Id}$. at 820 .

${ }^{85}$ United States v. Kincade, 379 F.3d 813, 820 (9th Cir. 2004).

${ }^{86} \mathrm{Id}$.
}

Journal of Technology Law \& Policy

Volume XVI - Fall 2015 • ISSN 2164-800X (online)

DOI 10.5195/tlp.2015.178 • http://tlp.law.pitt.edu 
imprisonment. ${ }^{87}$ Kincade was eventually forced to submit a blood sample once he was incarcerated, but continued to challenge the constitutionality of the DNA Act. ${ }^{88}$

The Ninth Circuit held that the DNA Act was constitutional under the totality of the circumstances analysis utilized by the Fourth Circuit in Jones v. Murray. ${ }^{89}$ The court held that the state's interest in essentially monitoring convicted felons after their release from incarceration was substantial enough to warrant the DNA Act. ${ }^{90}$ The majority held that the DNA Act would be constitutional even if no special need existed, and that society's interest in protecting the public was so great as to allow for suspicionless searches of a previous offender's person and property. ${ }^{91}$ The majority also notes the relative ease and lack of invasiveness of a traditional blood sample. ${ }^{92}$

In a somewhat different approach, the Second Circuit upheld a Connecticut statute that required convicted felons to provide the state with a DNA sample under a special needs analysis. ${ }^{93}$ In Roe v. Marcotte, respondent was convicted of sexual assault and was sentenced to twenty-five years in prison. ${ }^{94}$ Shortly after his conviction, Connecticut passed a statute requiring that blood samples be taken from prisoners convicted of criminal sexual offenses and stored in a state-run database. ${ }^{95}$ Respondent refused to submit to the blood sample and raised an appeal under the Equal Protection Clause, specifically arguing that the statute targeted sexual offenders. ${ }^{96}$

The Second Circuit upheld the statute because the government's interest in protecting the public from sexual offenders creates a special need exception to the general rule that there must be individualized suspicion. ${ }^{97}$ According to the Supreme

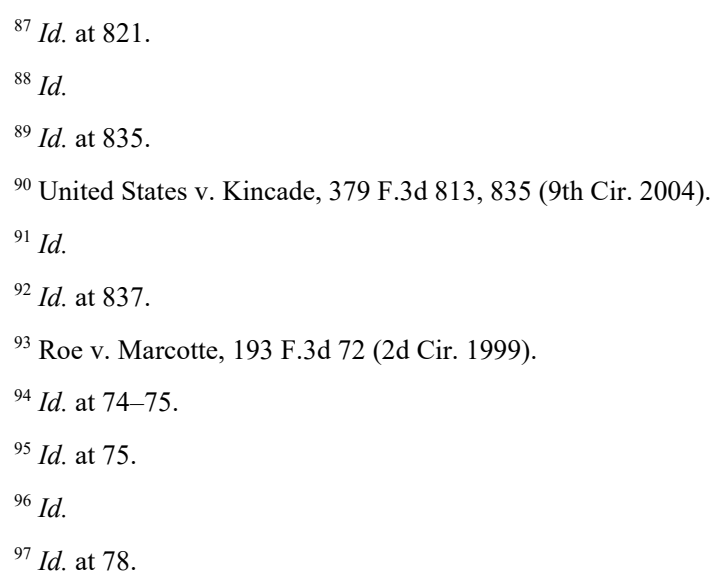


Court, ${ }^{98}$ a special needs exception can exist in order to support a significant government interest, such as public safety. ${ }^{99}$ The Second Circuit held that the Connecticut statute at issue fit into the special needs exception because of the high rate of recidivism among sexual offenders. ${ }^{100}$ Furthermore, DNA analysis is an essential part of capturing sexual predators, so storing DNA information would greatly aid government officials in tracking down the perpetrators of those crimes. ${ }^{101}$ The court also noted that sexual offenders will be less likely to commit future crimes if they are aware that their DNA is on file already. ${ }^{102}$ The majority balanced those legitimate government interests against the intrusion of a blood sample from the respondent, and held that the government's interest is too large to be subdued by that minor invasion of privacy. ${ }^{103}$ The Second Circuit further held that the statute did not violate the Equal Protection Clause because respondent's claim was entitled only to rational basis review, since he is not part of a protected class of people, and that the state did have a legitimate interest in protecting the public by keeping the DNA samples of sexual offenders on file. ${ }^{104}$

Other circuit courts have utilized the same rationales of Jones and Roe in their own jurisdictions, with every single state government and the federal government requiring DNA samples to be collected from convicted felons. ${ }^{105}$ The DNA databases kept by the states have helped to catch criminals, and studies have indicated that felonies are less likely to be committed if people are aware that their DNA will be kept on file. ${ }^{106}$ Due to the success of the DNA database program, states and the federal government have started to pass statutes authorizing a DNA sample to be taken from an individual arrested for a felony, rather than only those convicted of a felony. ${ }^{107}$

${ }^{98}$ See O'Connor v. Ortega, 480 U.S. 709 (1987) (holding that warrantless searches and seizures are constitutional in order to promote order and stability in hospitals).

${ }^{99}$ Roe v. Marcotte, 193 F.3d 72, 79 (2d Cir. 1999).

${ }^{100} \mathrm{Id}$.

${ }^{101} I d$.

${ }^{102} I d$.

${ }^{103} \mathrm{Id}$. at 80 .

${ }^{104} I d$. at 82 .

${ }^{105}$ Keagan D. Buchanan, Note, The Twenty-First Century Fingerprint: Previewing Maryland v. King, 4 CAlif. L. ReV. CiR. 38, 38 (2013).

${ }^{106} \mathrm{Id}$.

${ }^{107}$ Id. at 39.

Journal of Technology Law \& Policy

Volume XVI - Fall 2015 • ISSN 2164-800X (online)

DOI 10.5195/tlp.2015.178 • http://tlp.law.pitt.edu 
The Supreme Court considered the constitutionality of those statutes in Maryland v. King. ${ }^{108}$ Maryland's DNA Act allows police officers to take a suspect's DNA sample upon his arrest for certain serious crimes, even before he has been convicted of any crime. ${ }^{109} \mathrm{King}$ was arrested for first degree assault in 2009. ${ }^{110}$ The police took a DNA from him at the time of his arrest and entered it into their DNA system. ${ }^{111}$ The system matched King's DNA with DNA that had been collected in 2003 as evidence in an unsolved rape case. ${ }^{12}$ King was then arrested and charged with the rape from 2003. ${ }^{113} \mathrm{He}$ challenged the constitutionality of Maryland's DNA Act. ${ }^{114}$

The majority held that a Fourth Amendment search had taken place when King's mouth was swabbed upon his arrest. ${ }^{115}$ The Court analyzed King's claim under a totality of the circumstances approach, and noted that the process of rubbing a cotton swab along the interior of the mouth is a relatively minor intrusion. ${ }^{116}$ The Court also noted that there was probable cause when King was arrested and when the DNA sample was extracted. ${ }^{117}$ The Court held that Fourth Amendment jurisprudence needs to be assessed according to reasonableness, rather than individualized suspicion. ${ }^{118}$ The Court held that the government had a strong interest in collecting and storing the identity of the person being arrested. ${ }^{119}$ The Court noted that a search incident to an arrest is a standard police procedure. ${ }^{120}$

The Court discussed in detail why the state has a legitimate interest in taking DNA samples of arrestees during the booking process. ${ }^{121}$ First, the court stressed the

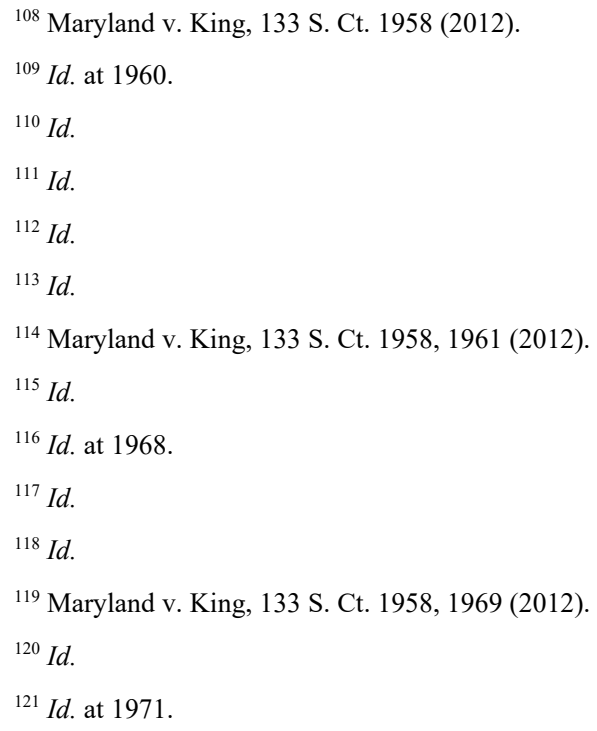


importance of DNA analysis to identification. ${ }^{122}$ The majority analogized DNA analysis and collection to that of the mandatory fingerprinting procedures that accompany arrest. ${ }^{123}$ The Court noted that the only difference between DNA and fingerprints are that DNA analysis is much more reliable. ${ }^{124}$ Secondly, the Court noted that law enforcement officials also have a duty to be informed about the type of person they are dealing with in order to ensure a safe environment. ${ }^{125}$ DNA analysis allows law enforcement to gain access to whether the arrestee has been involved with any other violent crimes in the past. ${ }^{126}$ Third, the Court stated that the government has a further interest in making sure that the person accused of a crime can be made available for trial. ${ }^{127}$ The Court reasoned that if a person has been arrested for one crime, but has knowingly committed another before that he has not been charged with, he may be incentivized to flee in order to escape justice, since a DNA sample will be taken once he is convicted that would link him to the other crime. ${ }^{128}$ Fourth, the Court found that an arrestee's past crimes are a useful indictor of whether or not that person should be released on bail. ${ }^{129}$ Lastly, the "interests of justice" supported collecting DNA samples from arrestees because it could release a prisoner who had been wrongly convicted in place of the arrestee. ${ }^{130}$ Therefore, the state has a legitimate interest in obtaining DNA samples from arrestees upon booking. ${ }^{131}$

The Court upheld the Maryland law because of the legitimate government interest in obtaining the DNA samples and the relatively minor inconvenience to the arrestee. The Court noted that the DNA sample taken was done in a painless and quick manner, and that the DNA sample itself could only be used for identification purposes. ${ }^{132}$ The Court was further influenced by analogizing DNA samples to the

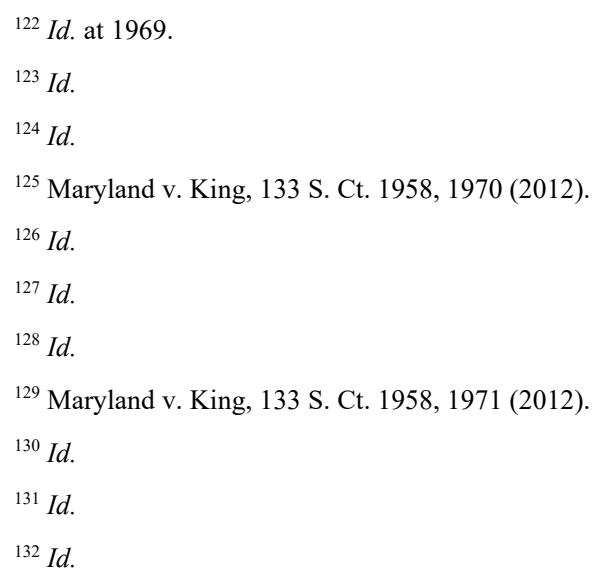

Journal of Technology Law \& Policy

Volume XVI - Fall 2015 • ISSN 2164-800X (online) DOI 10.5195/tlp.2015.178 • http://tlp.law.pitt.edu 
use of fingerprinting or photographing, both of which are currently utilized in every jurisdiction for arrestees without complaint or injury to justice. ${ }^{133}$

\section{PART IV: DNA ANALYSIS AND MICROBIOMES}

DNA analysis has helped solve countless cases and also exonerate innocent people who were wrongfully convicted of crimes. ${ }^{134}$ While DNA analysis has become an important forensic tool, it is has some disadvantages. ${ }^{135}$ One common problem associated with DNA analysis is the difficulty in obtaining the sample itself. ${ }^{136}$ Although scientists need only a small amount of DNA in order to analyze the sample, it may still be difficult for technicians to find any sample at all, especially if the criminal was careful. ${ }^{137}$ The search for a sample may be exasperated because there is no reliable way to look for it; technicians must rely on educated guesses or testing random areas and hope to find a match. ${ }^{138}$

Another problem arises when scientists have a DNA sample that has been mixed with the DNA of a different individual. ${ }^{139}$ In that circumstance, scientists must rely on their own subjective interpretations and assumptions in order to properly analyze the sample. ${ }^{140}$ Mixtures may pose an even greater threat of error when the samples are small. ${ }^{141}$ It is also not uncommon to find low levels of DNA on surfaces, regardless of whether a crime occurred or not. ${ }^{142}$ Therefore, it can be difficult to determine if the DNA was there before the crime occurred or if it belongs to a perpetrator of the crime. ${ }^{143}$

\section{${ }^{133}$ Id. at 1975 .}

${ }^{134}$ DNA Exonerations Nationwide, THE INNOCENCE PROJECT, http://www.innocenceproject.org/ Content/DNA_Exonerations_Nationwide.php (noting there have been 325 post-conviction exonerations due to DNA analysis to date).

${ }^{135}$ Forensic DNA Analysis Strengths and Limitations, Wyndham Forensics Group, Inc. (Fall 2009), http://www.wyndhamforensic.ca/resources/resources/Wfg_DNA_Nov09.pdf.

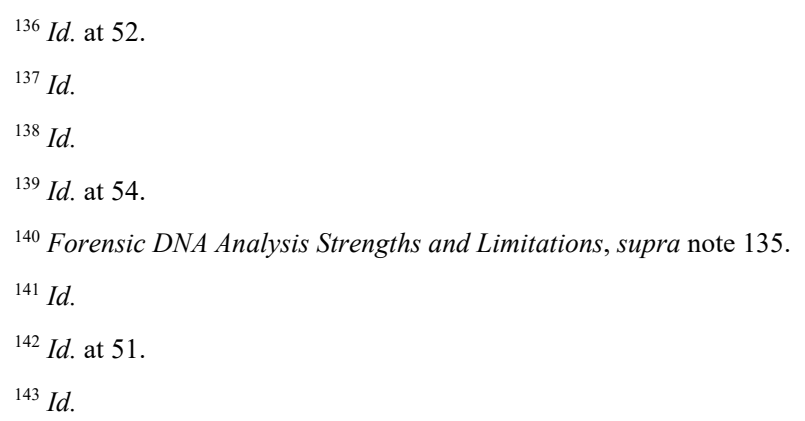


Microbiomes can help to alleviate some of the problems associated with DNA analysis. ${ }^{144}$ Microbiomes will be present on the body of a victim even when the perpetrator has not left any DNA behind. ${ }^{145}$ Microbiomes can also be used to track down criminals in a more effective manner than DNA because an individual will leave behind a microbiome fingerprint within a short time of being anywhere. ${ }^{146}$ Microbiomes have enormous potential to work in tandem with DNA analysis to both solve crimes and to track down perpetrators that may be fleeing justice, but it is important to consider the ethical and constitutional limits to both of those techniques.

\section{PART V: ETHICAL CONCERNS}

The Supreme Court's ruling in Maryland v. King found that statutes allowing DNA to be collected from individuals who are merely accused of a crime are constitutional. ${ }^{147}$ One result of that holding is that there will be more people subjected to a DNA collection, thereby increasing the general storage of DNA in a database. The greater number of samples in the database could potentially raise the probability of an innocent person being arrested for the crime because it increases the probability of false matches. ${ }^{148}$ Furthermore, the information contained in DNA is unduly expansive; aside from physical characteristics, DNA can indicate what genetic markers and possible diseases a person may contract or be at risk for in their lifetime. ${ }^{149}$ Despite the concern surrounding DNA databases and the intrusion into the right of privacy, ${ }^{150} \mathrm{DNA}$ analysis and databases have been deemed constitutional against persons who should be presumed innocent. ${ }^{151}$

Researchers have already begun mapping out the human microbiome in a project similar to the Human Genome Project, called the Human Microbiome Project ("HMP"). ${ }^{152}$ The HMP was launched in 2007 with the purpose of better

${ }^{144}$ Algar, supra note 7.

${ }^{145} \mathrm{Id}$.

${ }^{146}$ Fox, supra note 1.

${ }^{147}$ King, 133 S. Ct. at 1970.

${ }^{148}$ Is it Ethical to Have a National DNA Database?, YourGenOME (Jan. 14, 2015), http://www .yourgenome.org/debates/is-it-ethical-to-have-a-national-dna-database.

${ }^{149} I d$.

${ }^{150}$ Andrea Roth, Maryland v. King and the Wonderful, Horrible DNA Revolution in Law Enforcement, http://moritzlaw.osu.edu/students/groups/osjcl/files/2013/12/16.-Roth.pdf.

${ }^{151}$ King, 133 S. Ct. at 1970.

${ }^{152}$ The Human Microbiome, NIH HuMAN MicroBIOME PROJECT, http://www.hmpdacc.org/ overview/about.php.

Journal of Technology Law \& Policy

Volume XVI - Fall 2015 • ISSN 2164-800X (online)

DOI 10.5195/tlp.2015.178 • http://tlp.law.pitt.edu 
understanding health and predispositions to diseases, in addition to devising new strategies for manipulating the human microbiome. ${ }^{153}$ However, some researchers are concerned about the possibility of stigmatizing individuals, due to the fact that microbiomes have the potential to reveal eating habits, places recently traveled, drugs or tobacco ingested, or sexual practices. ${ }^{154}$ A database that could store that kind of private information has the potential to facilitate employment discrimination or other unfair treatment against people of certain races or sexual orientations. ${ }^{155} \mathrm{In}$ light of all of the private information the microbiome could reveal about an individual, it is useful to analyze how the Fourth Amendment would factor into privacy protections.

Since the collection of microbiomes are similar to the collection of DNA, it is reasonable to think that the Supreme Court would treat the two the same. Therefore, the Supreme Court would probably allow for the collection of microbiomes both at crime scenes and during police questioning, as in Maryland v. King. ${ }^{156}$ That case would allow each person's microbiome to be taken and examined, even if that person was only there for questioning and has yet to be convicted of a crime. ${ }^{157}$ That decision has allowed for an ever-expanding database of DNA, which is worrisome in itself, but a collection that is largely composed of an individual's microbiome could potentially have even more dire consequences. A database composed of microbiomes could perpetuate unfair treatment to people with certain characteristics, or it could potentially be hacked into and utilized by terrorist groups to expose certain segments of the population.

A government database composed of DNA is a privacy concern, but whereas DNA can only reveal the identity of someone, microbiomes have the potential to reveal a great deal of information about an individual. Microbiomes have the potential to reveal some very private aspects of a person's life and they should therefore be used with caution. Microbiomes can and should be a useful part of any criminal investigation. They have the potential to help officers track down criminals in a way that DNA cannot because each person will leave a trace of their microbiome behind wherever they visit. The microbiome can also help track down a criminal because it reveals where the perpetrator may have been before that as well, which

${ }^{153}$ Symposium, Are Changes to the Common Rule Necessary to Address Evolving Areas of Research? A Case Study Focusing on the Human Microbiome Project, 41 J.L. MED. \& ETHICS 454, 45477 (2013).

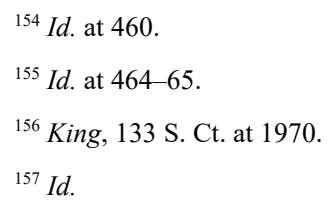


could lead investigators to other conspirators. However, while microbiomes should be used in that manner, they should not be kept and stored in a governmental database the way that DNA is kept and stored.

The Supreme Court in Maryland v. King ${ }^{158}$ reasoned that the collection and storage of DNA was quick and painless procedure, and that the government has a strong interest in catching criminals and therefore should be allowed to store that information. The worrisome logic behind that decision could potentially allow for a similar result with regards to the collection and storage of microbiomes. Microbiomes are quick and painless to obtain as they are usually obtained in the same way as DNA is, with a swab to the mouth or hands or feet, and they have the potential to reveal who was at the scene of the crime when it was committed. However, the Supreme Court should make a distinction between DNA and microbiomes because microbiomes also reveal the race and sexual orientation of the individual which, aside from discrimination concerns, is also an invasion of privacy under the Fourth Amendment.

In the landmark decision of Griswold v. Connecticut, ${ }^{159}$ the Supreme Court recognized a right to privacy. Although the Court has downplayed the right to privacy in Maryland $v$. King, ${ }^{160}$ the right to privacy remains an integral part of any Fourth Amendment analysis. Microbiomes should not be analyzed under the standard set forth in King, but rather through the totality of the circumstances test utilized in Jones. ${ }^{161}$ Under the totality of the circumstances test, a court would need to balance the interest of the government in collecting and maintaining a database of microbiomes against the individual's right to privacy. Considering the amount of information that an individual's microbiome may potentially reveal, courts should view the right to privacy as more important than it was in cases such as King ${ }^{162}$ and Jones. ${ }^{163}$ Courts should also find that since an individual's microbiome changes minimally in response to environmental stimuli, a database would do little to advance government interests.

Microbiome analysis has the potential to revolutionize the way in which doctors and researchers treat medical conditions. Microbiomes also have the potential to play a critical role in aiding law enforcement officers in catching fugitives, since

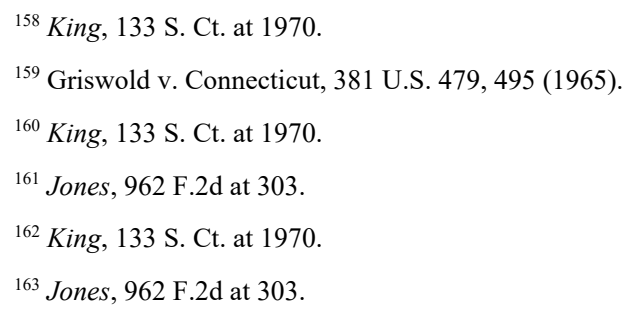

Journal of Technology Law \& Policy

Volume XVI - Fall 2015 • ISSN 2164-800X (online) DOI 10.5195/tlp.2015.178 • http://tlp.law.pitt.edu 
microbiomes can present officers with more information than a simple DNA analysis. However, because microbiomes can present more information about an individual than DNA analysis, the Supreme Court should make a distinction between the legality of the two methods. Under Maryland v. King, ${ }^{164}$ the Supreme Court currently allows law enforcement officers to collect and store the DNA of criminal suspects, even before they have ever been found guilty of the crime. Microbiomes can reveal more personal information about suspects than simply their identity, such as an individual's drug habits, race, sexual orientation, or other personal habits. Microbiomes should therefore trigger Fourth Amendment protection, and should not be stored in a national government database. While microbiomes can be a useful tool for law enforcement in the future, they need to be cautiously evaluated in order to determine when and where they should be kept and analyzed, and protocols should be implemented that would ensure the destruction of the microbial evidence after law enforcement has successfully captured the criminal.

${ }^{164}$ King, 133 S. Ct. at 1970.

M I C R O B I O M E S G E M C L O U D S

Volume XVI - Fall 2015 • ISSN 2164-800X (online)

DOI 10.5195/tlp.2015.178 • http://tlp.law.pitt.edu 